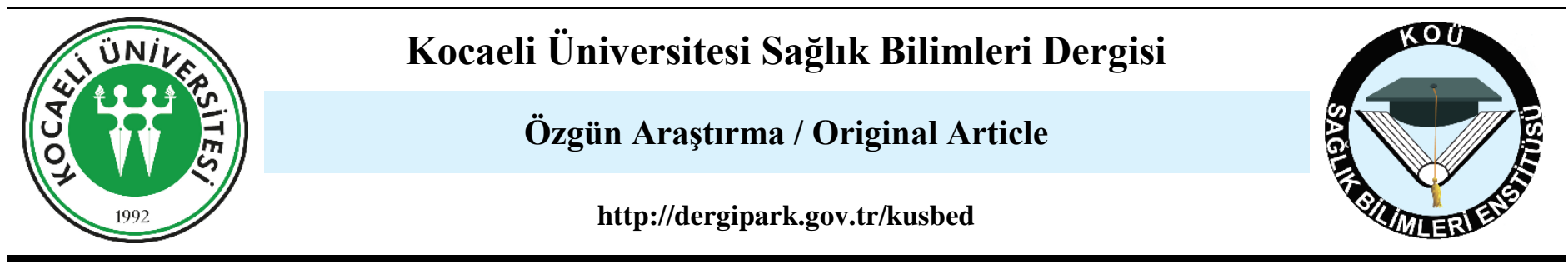

\title{
IS THERE A RELATIONSHIP BETWEEN PHYSICAL ACTIVITY LEVEL AND CORE ENDURANCE?
}

\author{
FIZIKSSEL AKTIVITE SEVIYESİ ILE KOR ENDURANSI ARASINDA ILISSKİ VAR MIDIR?
}

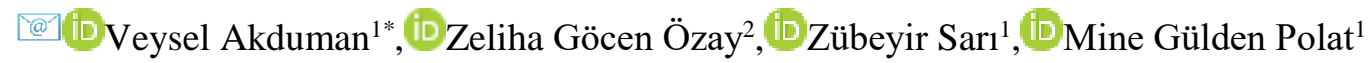

\begin{abstract}
${ }^{1}$ Marmara University, Faculty of Health Science, Istanbul, Turkey
${ }^{2}$ Fizyotouch Healthy and Happy, Izmir, Turkey
\end{abstract}

ORCID iD: Veysel Akduman: 0000-0002-4981-6049; Zeliha Göcen Özay: 0000-0001-5638-8356; Zübeyir Sar1: 0000-0003-1643-5415;

Mine Gülden Polat: 0000-0002-9705-9740

*Sorumlu Yazar / Corresponding Author: Veysel Akduman, e-posta / e-mail: veysel.akduman@marmara.edu.tr

Geliş Tarihi / Received: 02.11.2018

Kabul Tarihi / Accepted: 12.04.2019

Yayım Tarihi / Published: 20.05 .2019

\begin{abstract}
Objective: The aim of this study was to determine the relationship between core endurance and physical activity level in healthy young adults. Methods: This study was conducted with 310 university students [male=154 (49.7\%) and female=156 (50.3\%)] aged between 17 and 28 who attended Dokuz Eylul University. A sociodemographic data form was filled by all participants. Physical activity levels of the students were evaluated using the International Physical Activity Questionnaire (IPAQ). Core endurance was measured using anterior and right/left plank tests.

Results: The average anterior plank test period of the participants was $77.0 \pm 43.8 \mathrm{sec}$. and the average lateral plank test period was $43.9 \pm 28.0 \mathrm{sec}$. We found that $14.8 \%(n=46)$ of the participants were inactive, $48.1 \%(n=149)$ were minimally active, and $37.1 \%$ ( $n=115)$ were very active, according to the IPAQ. According to the IPAQ data, vigorous physical activity, moderate physical activity, and walking variables in male participants were significantly higher than female participants $(p<0.05)$. Plank test periods (anterior and lateral) of participant which have vigorous and moderate physical activity was significantly higher $(p<0.05)$.

Conclusion: There was no statistically significant relationship between core endurance and physical activity level. According to this study, physical activity is not influenced by core endurance. Particularly, in order to protect or increase the endurance of the core muscles, which have an important role in the prevention of mechanical lumbar problems, it was thought that only physical exercises would not be sufficient and it should be performed special exercises for these muscles.
\end{abstract}

Keywords: Core stability, core endurance, physical activity, students, physical endurance

$\ddot{\mathbf{O} z}$

Amaç: Bu çalışmanın amacı, sağlıklı genç erişkinlerde kor enduransı ile fiziksel aktivite seviyesi arasındaki ilişkiyi belirlemekti.

Yöntem: Bu çalışma, Dokuz Eylül Üniversitesi'nde okuyan yaşları 17 ile 28 arasında değişen 310 üniversite öğrencisiyle [erkek=154 (\%49,7) ve kadın=156 $(\% 50,3)]$ yapılmıştır. Sosyodemografik veri formu tüm katılımcılar tarafından doldurulmuştur. Öğrencilerin fiziksel aktivite düzeyleri Uluslararası Fiziksel Aktivite Anketi (UFAA) kullanılarak değerlendirildi. Kor enduransı ise anterior ve lateral plank testleri ile ölçüldü.

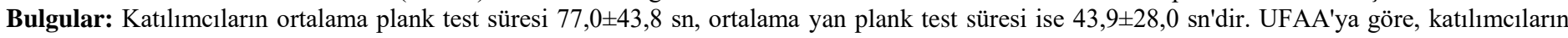
\%14,8'i (n=46) inaktif, \%48,1 (n=149) minimal aktif ve \%37,1 (n=115) çok aktifti. UFAA verilerine göre erkek ve kız ögrenciler arasında şiddetli fiziksel aktivite, orta şiddetli fiziksel aktivite ve yürüme değişkenlerinde erkek katılımcıların skoru anlamlı olarak daha yüksekti $(p<0,05)$. Şiddetli ve orta şiddetli fiziksel aktivite yapan katılımcıların plank test süreleri anlamlı olarak daha fazlaydı $(p<0,05)$.

Sonuç: Yapılan analizler sonucunda fiziksel aktivite seviyesi ile kor kasların enduransı arasında ilişki bulunamadı. Özellikle mekanik bel problemlerinin önlenmesinde önemli yeri olan kor kaslarının enduransının korunması veya artırılması için sadece fiziksel olarak aktif olmanın yetmeyeceği, bu kaslara yönelik özel egzersizlerin yapılması gerektiği düşünmüştür.

Anahtar Kelimeler: Kor stabilitesi, kor enduransl, fiziksel aktivite, öğrenciler, fiziksel endurans 


\section{Introduction}

The term "core" is described as a box that comprise the abdominal muscles in the front, paraspinal and gluteal muscles in the back, the diaphragm as the roof, and the pelvic floor and hip muscles as the bottom. ${ }^{1}$ Core refers to the lumbopelvic-hip complex, including deep muscles such as the internal oblique, transversus abdominis, transversospinalis, quadratus lumborum, and psoas major/minor and also superficial muscles such as the rectus abdominis, external oblique, erector spinae, latissimus dorsi, gluteus maximusmedius, hamstrings, and rectus femoris. ${ }^{2}$ It is reported that a single muscle is not responsible for maintaining stability in the lumbar region and 29 muscles are responsible for stabilizing the spine and pelvis during functional movements. ${ }^{3}$ Therefore, most of the muscles that stabilize the upper and lower limbs are attached to the core. Without the core muscles, the spine cannot maintain its stability against even the slightest compressive forces. ${ }^{4}$ Willardson stated that the core muscles must maintain balance in the spine to produce force in the lower and upper extremities and maintain desired movement. ${ }^{5}$ Many studies have demonstrated that the core muscles are important in providing stability of the abdomen, back, spine, and hip and creating the force required for trunk rotation. .,6 $^{2}$

The term "core stability" has become particularly important in recent years. Core stability is a general term used for the training of abdominal and lumbopelvic regions. A combination of local and global stability systems is used to describe core stability. ${ }^{7}$ Global muscles (erector spinae, rectus abdominis, quadratus lumborum, and transversus abdominis) are ideal for creating rotation and trunk movement owing to the long moment arms that extend from the pelvis to the thorax. $^{8}$ The local muscles (multifidi, rotators, and diaphragm) are short muscles that are directly attached to the vertebrae and are primarily responsible for producing sufficient strength for the segmental stability of the spine. ${ }^{9}$ Coordinated working of these muscles is important for spinal stability. ${ }^{4}$

However, core strength and core endurance are not the same. Core strength is defined as the resistance of the core muscles during any movement. Individuals must have the right posture and a sufficient level of core strength to maintain this balance. Another benefit of the core strength and correct posture is the therapeutic role they provide for individuals with chronic back pain. ${ }^{10}$ Core endurance, or stabilization, is defined as the ability of the core muscles to sustain this resistance. ${ }^{11}$ Kibler et al. stated that core stability is the ability to control the movement and position of the trunk over the pelvis and that it helps an individual to maintain their balance. ${ }^{12}$ Studies have also shown that decreased endurance of the back muscles is strongly associated with lumbar disc hernia. ${ }^{13,14}$

Movements such as running and bouncing are often unstable and require neuromuscular control to improve performance and maintain stability. ${ }^{15}$ Disorders in neuromuscular control of the core muscles may cause injury, as well as unstable behavior, throughout all segments of the kinetic chain ${ }^{16}$. Proprioceptive disorder of the core may cause a reduction in active neuromuscular control of the lower and upper extremities. ${ }^{14,16}$ Durability/stabilization and the strengthening and training of the thigh, trunk, and hip are also important for preventing athletic injuries. For this reason, core stability is important for individuals engaged in any sport. ${ }^{17}$

Body movement that increases energy expenditure at the basal level by skeletal muscle contraction is called "physical activity". ${ }^{18}$ In summary, any activity that increases energy expenditure is called physical activity. ${ }^{19}$ Muscle strength, body balance, aerobic capacity, and metabolic and immunological functions have been observed to develop in individuals with regular physical activity (Task Force on Community Preventive Services); these attributes, as well as physical activity, were found to have the following positive effects in these individuals: increased endurance, strength and flexibility, strengthened bones and muscles, improved social relations, and increased self-confidence. ${ }^{20}$ Given the benefits of physical activity, individuals and communities must be encouraged to be involved with an appropriate level of physical activity in order to achieve maximum health benefits. It is clear that physical activity is necessary for increasing quality of life and extending life span. ${ }^{21}$

A single session of physical activity is expressed as the duration of physical activity. The data for the duration of personal training sessions can be used to determine the total minutes of activity with frequency data. For example, if the absolute intensity of physical activity is estimated in an ordinary week, the weekly clear or gross energy expenditure can be expressed as kJ (kilojoule) or MET (Metabolic Equivalent of Task). The number of physical activities performed at a given time is referred to as the "physical activity frequency".22 The most useful physical activity frequency for an individual is spread over 5 days, and physical activity should be lifelong in order to be beneficial to health. ${ }^{23}$ Physical activity done regular and quality is more important than severe physical activity. ${ }^{24}$ For this reason, physical activity must be performed in a proper and controlled manner. Many studies have indicated that physical activity of the core muscles provides core stabilization, which reduces injuries of the lower and upper extremities. An individual's early health-related behaviour will influence future lifestyle, and, for this reason, it is important to investigate health behaviours of young individuals. ${ }^{25}$

This study aimed to determine physical activity levels in young individuals, the effect of physical activity on core endurance and effect of gender on these parameters.

\section{Methods}

\section{Samples}

This study comprised 377 students aged 17-28 years studying at Dokuz Eylul University, and these students agreed to participate in the study. Due to the inability to complete the test part of the study and missing data due to the absence of 67 participants, 310 participants completed the study. Of these participants, 154 (49.7\%) were male and 156 (50.3\%) were female. Inclusion criteria were as follows: to be a university student, signature on a consent form confirming voluntary participation in the research, and no any physical therapy and/or rehabilitation treatment within the last 6 months. Exclusion criteria were as follows: any physical condition obstructing walking; pulmonary, cardiovascular, and neurological disabilities; and pregnancy. The demographic characteristics of the participants are shown in Table 1.

After the approval of the Ethics Committee of Sifa University, the research was applied to the participant (Reference No: 268-71) and the study was conducted in compliance with the Helsinki Declaration. 


\section{Data collection tools}

\section{Sociodemographic data form}

A form was prepared by the authors to assess sociodemographic characteristics such as age, gender, characteristics related to smoking and non-alcohol use, known physical illnesses and medications used. In addition, the participant's body weight, height and body mass index (BMI) was calculated and recorded.

\section{Endurance tests}

We assessed core endurance via plank tests. Plank tests provide an endurance assessment during an activity that is applied as anterior and right and left lateral plank tests and simulate muscles ${ }^{1}$. McGill et al. reported that there was no difference in the right and left lateral plank tests, and therefore we tested the lateral plank position only on the dominant side of the participants. ${ }^{26}$

Core endurance was measured using plank tests in two positions (anterior and lateral) using procedures previously described. ${ }^{27,28}$ Participants first performed a single practice trial for a few seconds to confirm ability to successfully attain the test position. Later, the participants performed a recorded test. The maximum time -second (s)- that the participants were able to take and maintain the correct test position was recorded. The same examiner recorded the result of all tests by observation. For the anterior plank test, the participants performed a pushup: legs together, with the lower leg in contact with the floor mat; ankles with plantar flexion, back in a straight position; the shoulder width apart; and the head upwards (Figure 1). When any part of the participant's body was not parallel to the floor, the time was stopped as previously described. ${ }^{27}$

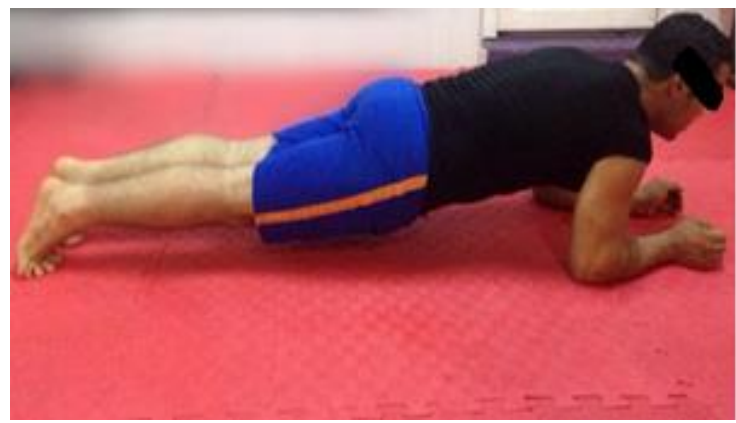

Figure 1. Anterior plank test

To perform the lateral plank test, participants placed one foot on top of the other, with the right arm perpendicular to the floor; the elbow was placed on the mat, with the arm across the chest; and the left hand was placed on the right shoulder (Figure 2).

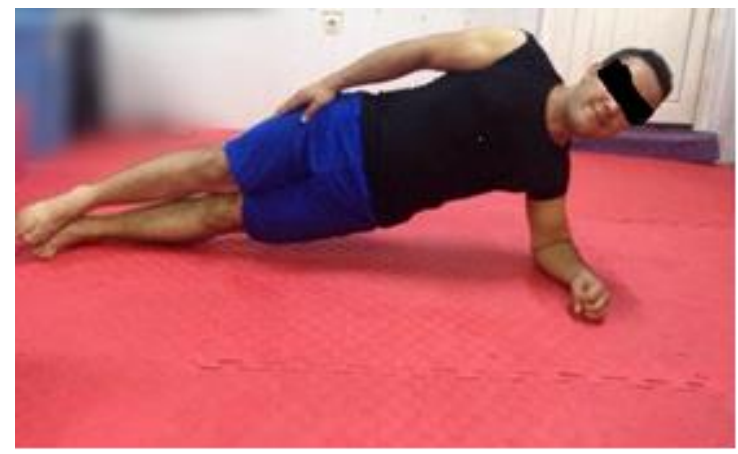

Figure 2. Lateral plank test
The researcher recorded the instance when the participants were unable to maintain a straight line between the trunk or lower body (thigh or shank) segments in the visual observation. ${ }^{28}$

\section{International Physical Activity Questionnaire short form}

The International Physical Activity Questionnaire (IPAQ) short form was used to determine the physical activity levels of the participants. The IPAQ short form comprises seven questions measuring physical activity level. Participants were questioned whether they had performed severe, moderate, or low physical activity in the last 7 days, as well as walking and sitting. The total weekly physical activity level of participants (MET/h/week) from these data was classified as inactive ( $<600 \mathrm{MET} \mathrm{min} /$ week), minimally active (>600-3000 $\mathrm{MET} /$ week), or active $(<3000 \mathrm{MET} /$ week). One MET is approximately equal to $3.5 \mathrm{ml} / \mathrm{kg} / \mathrm{min}$ in adults, which is equal to energy expenditure during rest. ${ }^{29}$

\section{Statistical Analysis}

The normal distribution suitability of the variables was examined using statistical analysis (Kolmogorov-Smirnov test). Descriptive statistics (minimum, maximum, and average) were calculated for demographic variables as well as the IPAQ and the plank/lateral plank measurements. The relationship between independent groups was analyzed using independent sample $t$-test. Multivariate analysis of variance test was used to analyze the differences among IPAQ groups. The relationship between the quantitative parameters was calculated using Pearson's correlation test $(r \geq 0.50$ and $p \leq 0.05$ was accepted as the level of statistical significance for the correlation data). All test results were analyzed using Statistical Package for the Social Sciences 17.0 (SPSS Inc; Chicago, IL, USA) statistical software. The level of significance was set at $p<0.05$ for all analyses.

\section{Results}

The average age was $19.8 \pm 1.9$ years, the average body height was $171.8 \pm 9.3 \mathrm{~cm}$, the average body weight was $66.3 \pm 13.4$ $\mathrm{kg}$, and the average BMI was $22.3 \pm 3.2 \mathrm{~kg} / \mathrm{m}^{2}$ (Table 1).

Table 1. Demographic and anthropometric characteristics of participants

\begin{tabular}{l|ccc}
\hline Variable & Minimum & Maximum & Mean \pm SD \\
\hline Age (year) & 17 & 28 & $19.8 \pm 1.9$ \\
Height (cm) & 151 & 203 & $171.8 \pm 9.3$ \\
Weight (kg) & 40 & 110 & $66.3 \pm 13.4$ \\
BMI $\left(\mathrm{kg} / \mathrm{m}^{2}\right)$ & 15.6 & 34.3 & $22.3 \pm 3.2$ \\
\hline
\end{tabular}

Descriptive analysis was performed. BMI: Body Mass Index

Participants' smoking rate was $26.5 \%$ while alcohol use was $36.8 \%$. Table 2 shows average vigorous physical activity (IPAQ 1), moderate physical activity (IPAQ 3), walking (IPAQ 5), sitting (IPAQ 7), and the total IPAQ score as MET. Accordingly, the average total IPAQ score is $2548.2 \pm 1920.3$ MET, with a minimum of 300 MET and a maximum of 8648 MET. The participants' mean plank test duration was $77.0 \pm 43.8 \mathrm{~s}$, whereas the mean lateral plank test duration was $43.9 \pm 28.0 \mathrm{~s}$. 
Table 2. Mean of participants' IPAQ variables and plank tests

\begin{tabular}{l|ccc}
\hline IPAQ Accounts and Plank tests & Minimum & Maximum & Mean \pm SD \\
\hline Vigorous physical activity (MET) & 0 & 7200 & $958.8 \pm 1,386.2$ \\
Moderate physical activity (MET) & 0 & 4320 & $359.6 \pm 633.9$ \\
Walking (MET) & 0 & 4851 & $1,231.4 \pm 896.4$ \\
Sitting (MET) & 300 & 800 & $474.5 \pm 119.7$ \\
Total IPAQ (MET) & 300 & 8648 & $2,548.2 \pm 1,920.3$ \\
Plank (s) & 12 & 258 & $77.0 \pm 43.8$ \\
Lateral Plank (s) & 5 & 180 & $43.9 \pm 28.0$ \\
\hline
\end{tabular}

Descriptive analysis was performed. IPAQ: International Physical Activity Questionnaire; IPAQ I: Vigorous Physical Activity; IPAQ III: Moderate Physical Activity; IPAQ V: Walking; IPAQ VII: Sitting; MET: Metabolic Equivalent of Task

There was a statistically significant difference between male and female participants with respect to BMI, plank test duration, lateral plank test duration, severe physical activity (IPAQ 1), moderate physical activity (IPAQ 3), walking (IPAQ 5), and total IPAQ score (Table 3).

Table 3. Comparison of gender and evaluation parameters

\begin{tabular}{l|ccc}
\hline Scores & $\begin{array}{c}\text { Male } \\
(\mathbf{n = 1 5 4 )}\end{array}$ & $\begin{array}{c}\text { Female } \\
(\mathbf{n = 1 5 6})\end{array}$ & $\boldsymbol{p}$ value \\
\hline BMI & $23.3 \pm 3.7$ & $21.1 \pm 3.0$ & $<0.001^{*}$ \\
Plank (s) & $94.9 \pm 47.6$ & $59.4 \pm 32.1$ & $<0.001$ \\
Lateral Plank (s) & $53.9 \pm 32.7$ & $34.2 \pm 18.3$ & $<0.001$ \\
Vigorous physical activity (IPAQ 1) & $1,430.1 \pm 1,552.6$ & $493.6 \pm 1,006.4$ & $<0.001$ \\
Moderate physical activity (IPAQ 3) & $466.2 \pm 743.4$ & $254.5 \pm 482.9$ & 0.003 \\
Walking (IPAQ 5) & $1340.7 \pm 902.9$ & $1,120.8 \pm 881.5$ & 0.003 \\
Total IPAQ & $3,237.0 \pm 2,044.0$ & $1,868.8 \pm 1511.0$ & $<0.001$ \\
\hline
\end{tabular}

Independent sample $t$-test was performed. $* p<0.05$ was statistically significant. BMI: Body Mass Index; IPAQ: International Physical Activity Questionnaire

Severe and moderate physical activities and plank test time parameters of male participants were found to be significantly higher than women $(p<0.05)$.

There was no statistically significant difference between physical activity levels and plank and lateral plank test times ( $p=0.406$ and $p=0.455$, respectively) (Table 4).

Table 4. Comparison of plank and lateral plank test durations and participants' physical activity levels

\begin{tabular}{l|cccc}
\hline Core endurance tests & $\begin{array}{c}\text { Inactive } \\
(\mathbf{n = 4 6 )}\end{array}$ & $\begin{array}{c}\text { Minimally } \\
\text { active }(\mathbf{n = 1 4 9})\end{array}$ & $\begin{array}{c}\text { Very active } \\
(\mathbf{n = 1 1 5})\end{array}$ & $\begin{array}{c}\boldsymbol{p} \\
\text { value }\end{array}$ \\
\hline Plank test time (s) & $68.9 \pm 35.8$ & $77.7 \pm 39.4$ & $79.0 \pm 52.4$ & 0.406 \\
Lateral plank test time(s) & $41.6 \pm 23.9$ & $42.5 \pm 23.8$ & $46.5 \pm 34.3$ & 0.455 \\
\hline
\end{tabular}

One-way Anova test was performed. $* p<0.05$ was statistically significant.

A statistically significant negative correlation $(p=0.004$, $r_{s}=-0.163$ ) was observed between the age and anterior plank test periods, whereas there was a statistically significant positive correlation between body weight and the anterior plank period ( $p=0.021, \mathrm{r}_{\mathrm{s}}=0.132$ ). There was no significant correlation between age and body weight and lateral plank test duration $(p>0.05)$. In addition, there was a moderate positive correlation between body height and plank and lateral plank periods $\left(p=0.0001, \mathrm{r}_{\mathrm{s}}=0.332 ; \quad p=0.0001\right.$, $r_{s}=0.283$, respectively) (Table 5).

There was a statistically significant positive strong correlation between plank test time and lateral plank test time ( $p=0.0001$, $\left.r_{s}=0.654\right)$. There was also a statistically significant positive correlation between the anterior plank test and lateral plank tests, severe physical activity, moderate physical activity, and total IPAQ values (Table 6).
Table 5. Comparison of plank and lateral plank test durations and participants' age, body weight and body height

\begin{tabular}{c|cccc}
\hline $\begin{array}{c}\text { Core endurance } \\
\text { tests }\end{array}$ & Statistic & Age & $\begin{array}{c}\text { Body } \\
\text { weight }\end{array}$ & $\begin{array}{c}\text { Body } \\
\text { height }\end{array}$ \\
\hline Plank test time (s) & $\mathrm{r}$ & $-0.163^{*}$ & 0.132 & 0.332 \\
& $p$-value & 0.004 & 0.021 & $<0.001$ \\
Lateral plank test & $\mathrm{r}$ & 0,045 & 0,095 & 0.283 \\
time(s) & $p$-value & 0,430 & 0,094 & $<0.001$ \\
\hline
\end{tabular}

Pearson Correlation test was performed. ${ }^{*} p<0.05$ was statistically significant.

Table 6. Relationship between participants' evaluation parameters

\begin{tabular}{|c|c|c|c|c|c|c|c|}
\hline Variables & Statistic & $\begin{array}{l}\text { Plan } \\
\mathrm{k}(\mathrm{s})\end{array}$ & $\begin{array}{l}\text { Lateral } \\
\text { Plank } \\
\text { (s) }\end{array}$ & $\begin{array}{c}\text { IPAQ } \\
\text { I }\end{array}$ & $\begin{array}{c}\text { IPAQ } \\
\text { III }\end{array}$ & $\begin{array}{c}\text { IPAQ } \\
\text { V }\end{array}$ & IPAQ Total \\
\hline Plank (s) & $\mathrm{r}$ & & 0.654 & 0.305 & $0.145^{*}$ & 0.061 & 0.269 \\
\hline & $P$-value & & $1 \mathrm{E}-04$ & $1 \mathrm{E}-04$ & 0.011 & 0.283 & $<0.001$ \\
\hline Lateral Plank & $\mathrm{r}$ & & & 0.214 & 0.143 & 0.074 & 0.195 \\
\hline (s) & $P$-value & & & $1 \mathrm{E}-04$ & 0.012 & 0.193 & 0.001 \\
\hline $\begin{array}{l}\text { Vigorous } \\
\text { Physical }\end{array}$ & $\mathrm{r}$ & & & & 0.309 & 0.092 & 0.751 \\
\hline Activity & $P$-value & & & & $<0.001$ & 0.106 & $<0.001$ \\
\hline $\begin{array}{l}\text { Moderate } \\
\text { Physical }\end{array}$ & $\mathrm{r}$ & & & & & 0.041 & 0.504 \\
\hline Activity & $P$-value & & & & & 0.470 & $<0.001$ \\
\hline Walking & $\begin{array}{l}\mathrm{r} \\
P \text {-value }\end{array}$ & & & & & & $\begin{array}{r}0.586 \\
<0.001\end{array}$ \\
\hline
\end{tabular}

Pearson Correlation test was performed. ${ }^{*} p<0.05$ was statistically significant mIPAQ I: Vigorous Physical Activity; IPAQ III: Moderate Physical Activity; IPAQ V: Walking.

\section{Discussion}

Core muscles are an important muscle group used not only in athletic activities but also in very basic activities of daily living, such as sitting and walking, and therefore should be strengthened in order to prevent posture disorders, back pain, and sports-related injuries. ${ }^{30}$ Core strength is an important issue for the health of both the individual and community. Physical activity should be a daily habit and maintained throughout the life. ${ }^{31}$ Performing physical activity early in life can help prevent health problems that may occur during old age. University students constitute a significant part of the young population in our country. Furthermore, physical activity levels in young individuals affect the incidence of many preventable diseases that constitute problems in old age. $^{32}$

In theory, it is accepted that core stability and physical activity are interrelated; however, current literature does not support this relationship. This study aimed to examine the relationship between core stability (using anterior plank and lateral plank tests) and physical activity levels (using IPAQ) in male and female university students.

According to IPAQ data of all participants, $14.8 \%$ were not physically active, $48.1 \%$ had low physical activity levels, and $37.1 \%$ had adequate physical activity levels. Savc1 et al. classified university students according to their total physical activity scores according to IPAQ data in 2006, $15 \%$ of students were not physically active, $68 \%$ of students had low physical activity levels, and $18 \%$ of students had sufficient physical activity levels to maintain health. ${ }^{33}$ In another study, $12.6 \%$ of participants were not physically active, $57.1 \%$ of participants had low physical activity levels, and $30.3 \%$ of participants had sufficient physical activity levels. ${ }^{34}$ These results show that the inadequacy of physical activity in university students is a significant issue; however, physical 
activity levels are annually increasing. It is thought that this increase may be related to a better understanding of the importance of physical activity for health. It was also found that $11 \%$ of men were not physically active, $66 \%$ had low physical activity levels, and $23 \%$ had adequate physical activity levels; whereas $17 \%$ of women were not physically active, 68\% had low physical activity levels, and 18\% had adequate physical activity levels. ${ }^{35}$ Our results corresponded with those of previous studies: male students had higher physical activity levels than those of female students. ${ }^{33,35,36}$ However, in contrast to these findings, there are studies indicating that women's physical activity levels are more. ${ }^{37}$

In this study, on comparing plank and lateral plank test times, we found isometric muscle endurance times of male students to be better than those of female students. ${ }^{38}$ Strand et al. studied isometric muscle endurance test norms in 471 university students and found that the plank test times of male students were significantly longer, which were similar to those observed in our study. ${ }^{38}$ In our study, there was a statistically significant relationship between body height and body weight, but there was no statistically significant relationship between plank and lateral plank test duration and BMI. These findings support the possibility that body height, BMI, and gender are determining factors in predicting core endurance times. It was also noted that there was a relationship between BMI and lower test durations because males were on an average taller and heavier than females; separate percentiles for endurance times according to gender are appropriate.

In the present study, there was no statistically significant difference between anterior plank and lateral plank tests. Similarly, in another core endurance test developed by McGill, including the lateral plank test, no significant difference was observed between the two tests. ${ }^{39}$

There was a statistically significant correlation among plank and lateral plank test periods, vigorous physical activity levels (IPAQ 1), moderate physical activity level (IPAQ 3), and total physical activity scores (IPAQ Total), according to the IPAQ data in our study. Increased vigorous physical activity resulted in increased anterior plank and lateral plank test times. However, activities such as walking and sitting in the IPAQ score did not affect the plank test times. However, there was no statistically significant relationship between physical activity levels and core endurance in our study. We think that physical activity levels may be related to core strength more than core endurance. However, further studies are required to determine the strength of the core muscles and the relationship between core strength and physical activity levels.

The present study has some limitations. Limited number of people were included in this study, since the subjects were recruited only from one university. In order to represent all the young population in the society, we believe that the number of samples in the design of the study should be increased and participants from different regions should be recruited. Another limitation of this study, a functional assessment on the physical activity levels obtained by objective methods would have further validated the results of this study.

Considering the results of the current study, physical activity level is not significantly affected by core endurance. Therefore, exercises to increase core endurance should be directed to core muscles. Furthermore, we think that physical activity may be related to core muscle strength and in the future there is a need for studies to determine the relationship of physical activity level to core strength.

\section{Acknowledgement}

The manuscript has been presented as a poster at the International Meeting on Education and Research in Health Sciences (IMER-HS) on 04.11.2017 in Istanbul/Turkey and was published as an abstract in Congress Web Site.

\section{Conflicts of Interest Statement}

The authors have no conflicts of interest relevant to this article.

\section{Funding/Support Statement}

This research did not receive any specific grant from funding agencies in the public, commercial, or not-for-profit sectors.

\section{References}

1. Bliss LS, Teeple P. Core stability: the centerpiece of any training program. Curr Sports Med Rep. 2005;4:179-183.

2. Saeterbakken AH, Fimland MS, Navarsete J, Kroken T, van der Tillaar R. Muscle activity, and the association between core strength, core endurance and core stability.J Nov Physiother Phys Rehabil.2015;1(1):028-034. doi:10.17352/24555487.000022

3. Axel TA. The Effects of a Core Strength Training Program on Field Testing Performance Outcomes in Junior Elite Surf Athletes [PhD thesis]. Long Beach: California State University; 2013.

4. Fredericson M, Moore T. Muscular balance, core stability, and injury prevention for middle-and long-distance runners. Phys Med Rehabil Clin $N \mathrm{Am}$. 2005;16:669-689. doi:10.1016/j.pmr.2005.03.001

5. Willardson JM. Developing the Core (1. Edition). Human Kinetics, Illınois, 2014

6. Shinkle J, Nesser TW, Demchak TJ, McMannus DM. Effect of core strength on the measure of power in the extremities. Strength Cond Res. 2012;26:373-380. doi:10.1519/JSC.0b013e31822600e5.

7. Bergmark, A. Stability of the lumbar spine: a study in mechanical engineering Acta Orthop Scand. 1989;60(supp.230):1-54.

8. Hodges P, Holm AK, Holm S, et al. Intervertebral stiffness of the spine is increased by evoked contraction of transversus abdominis and the diaphragm: in $\begin{array}{llll}\text { vivo porcine } & \text { Studies. }\end{array}$ doi:10.1097/01.BRS.0000096676.14323.25

9. Stanford ME. Effectiveness of specific lumbar stabilization exercises: A single case study. J Man Manip Ther. 2002;10:40-46. doi:10.1179/106698102792209549

10. McGrath PJ, Walco GA, Turk DC, et al. Core outcome domains and measures for pediatric acute and chronic/recurrent pain clinical trials: PedIMMPACT recommendations. J Pain. 2008;9:771-783. doi: 10.1016/j.jpain.2008.04.007

11. Leetun DT, Ireland ML, Willson JD, Ballantyne BT, Davis IM. Core stability measures as risk factors for lower extremity injury in athletes. Med Sci Sports Exerc. 2004;36:926-934

12. Kibler WB, Press J, Sciascia A. The role of core stability in athletic function Sports Med. 2006:36:189-98 doi: 10.2165/00007256-200636030-00001

13. Nourbakhsh MR, Arab AM. Relationship between mechanical factors and incidence of low back pain. J Orthop Sports Phys Ther. 2002;32:447-460 doi:10.2519/jospt.2002.32.9.447

14. Zazulak BT, Ponce PL, Straub SJ, Medvecky MJ, Avedisian LA, Hewett TE. The effect of gender on hip muscle activity during landing. J Orthop Sports Phys Ther 2005;35:292-299. doi:10.2519/jospt.2005.35.5.292

15. Loram ID, Kelly SM, Lakie M. Human balancing of an inverted pendulum: is sway size controlled by ankle impedance? J Physiol. 2001;532:879-891.

16. Hewett TE, Myer GD, Ford KR, et al. Biomechanical measures of neuromuscular control and valgus loading of the knee predict anterior cruciate ligament injury risk in female athletes a prospective study. Am J Sports Med. 2005;33:492-501. doi:10.1177/0363546504269591

17. Samson KM, Sandrey MA, Hetrick AA. Core stabilization training program for tennis athletes. Athletic Therapy Today. 2007;12(3):41-46.

18. Baranowski T, Bouchard $\mathrm{C}$, Bar-Or O, et al. Assessment, prevalence, and cardiovascular benefits of physical activity and fitness in youth. Med Sci Sports Exerc. 1992;24:237-247.

19. McArdle WD, Katch FI, Katch VL. Exercise Physiology: nutrition, energy, and human performance. 7th. ed. Philadelphia, PA: Lippincott Williams and Wilkins; 2010

20. Can S, Arslan E, Ersöz G. Güncel Bakıs Açısı ile Fiziksel Aktivite. Ank. Üniv Spor Bil Fak. 2014;12:1-10.

21. Yüksel E. An Investigation of the Factors Influencing the Physical Activity Levels of Working Women [Master's thesis]. Ankara: Ankara University; 2001.

22. Shephard RJ. Limits to the measurement of habitual physical activity by questionnaires. Br. J. Sports Med. 2003;37:197-206. doi: 10.1136/bjsm.37.3.197

23. Sahebi A. Analysing the Correlation Between Physical Activity Level and Academic Achievement of University Students [Master's thesis]. Ankara: Gaz University; 2014

24. Haskell LW, Lee MI, Pate RR, et al. Physical activity and public health: updated recommendation for adults from the American College of Sports Medicine and the American Heart Association. Med Sci Sports Exerc. 2007;39:1423-1434. doi:10.1249/mss.0b013e3180616b27 
25. Von Bothmer MI, Fridlund B. Gender differences in health habits and in motivation for a healthy lifestyle among Swedish university students. Nurs Health Sci. 2005;7:107-118. doi:10.1111/j.1442-2018.2005.00227.x

26. McGill SM. Distribution of tissue loads in the low back during a variety of daily and rehabilitation tasks. J Rehabil Res Dev. 1997;34:448-458.

27. Allen BA, Hannon JC, Burns RD, Williams SM. Effect of a core conditioning intervention on tests of trunk muscular endurance in school-aged children. J Strength Cond Res. 2014;28:2063-2070. doi: 10.1519/JSC.0000000000000352

28. Ambegaonkar JP, Mettinger LM, Caswell SV, Burtt A, Cortes N. Relationships between core endurance, hip strength, and balance in collegiate female athletes. Int J Sports Phys Ther. 2014;9:604-616.

29. Saglam M, Arikan H, Savci S, et al. International physical activity questionnaire: reliability and validity of the Turkish version. Percept Mot Skills. 2010;111:278284. doi:10.2466/06.08.PMS.111.4.278-284

30. Granacher U, Schellbach J, Klein K, Prieske O, Baeyens JP, Muehlbauer T. Effects of core strength training using stable versus unstable surfaces on physical fitness in adolescents: a randomized controlled trial. BMC Sports Sci Med Rehabil. 2014;6:40. doi:10.1186/2052-1847-6-40

31. Memiş AD. Öğrencilerin çalışma oryantasyonlarını etkileyen demografik faktörler. Türk Eğitim Bilimleri Dergisi. 2007;5:291-322.
32. Özkan KA. Examination of Physical Activity Level of Kirikkale University Students Pedometer [Master's thesis]. Kırıkkale: Kırıkkale University; 2015.

33. Savcı S, Öztürk M, Arıkan H, İnce Dİ, Tokgözoğlu L. Üniversite öğrencilerinin fiziksel aktivite düzeyi. Türk Kardiyoloji Derneği Arşivi. 2006;34:166-172.

34. Abdurrahman G, Sener Ü, Karabacak H, Ücok K. Kadın ve erkek genç erișkinler arasında fiziksel aktivite ve yașam kalitesi farklılıklarının araștırılması. The Medical Journal of Kocatepe. 2011;12:145-150

35. Shibata A, Oka K, Nakamura Y, Muraoka I. Recommended level of physical activity and health-related quality of life among Japanese adults. Health Qual Life Outcomes. 2007;5:64. doi:10.1186/1477-7525-5-64

36. Fişne M. Examining the Effects of Physical Activity Level of University Students on Their Academic Achievement, Communication Skills and Life Satisfaction [Master's thesis]. Kayseri: Erciyes University; 2009.

37. Şanlı E, Güzel NA. Öğretmenlerde fiziksel aktivite düzeyi-yaş, cinsiyet ve beden kitle indeksi ilișkisi. Gazi Beden Eğitimi ve Spor Bilimleri Dergisi. 2008;14(3), 23-32.

38. Strand SL, Hjelm J, Shoepe TC, Fajardo MA. Norms for an isometric muscle endurance test. J Hum Kinet.2014;40:93-102. doi:10.2478/hukin-2014-0011

39. McGill SM, Childs A, Liebenson C. Endurance times for low back stabilization exercises: clinical targets for testing and training from a normal database. Arch Phys Med Rehabil. 1999;80:941-944. 